\title{
Antagonistic Activity of Plant Growth Promoting Fluorescent Pseudomonas spp. against Major Fungal Pathogens Involved in Replant Problem of Apple
}

\author{
Neha Kaushal* and Mohinder Kaur
}

Microbiology Research Laboratory, Department of Basic Sciences, Dr Y S Parmar University of Horticulture and Forestry, Nauni (Solan) Himachal Pradesh-173230, India

*Corresponding author

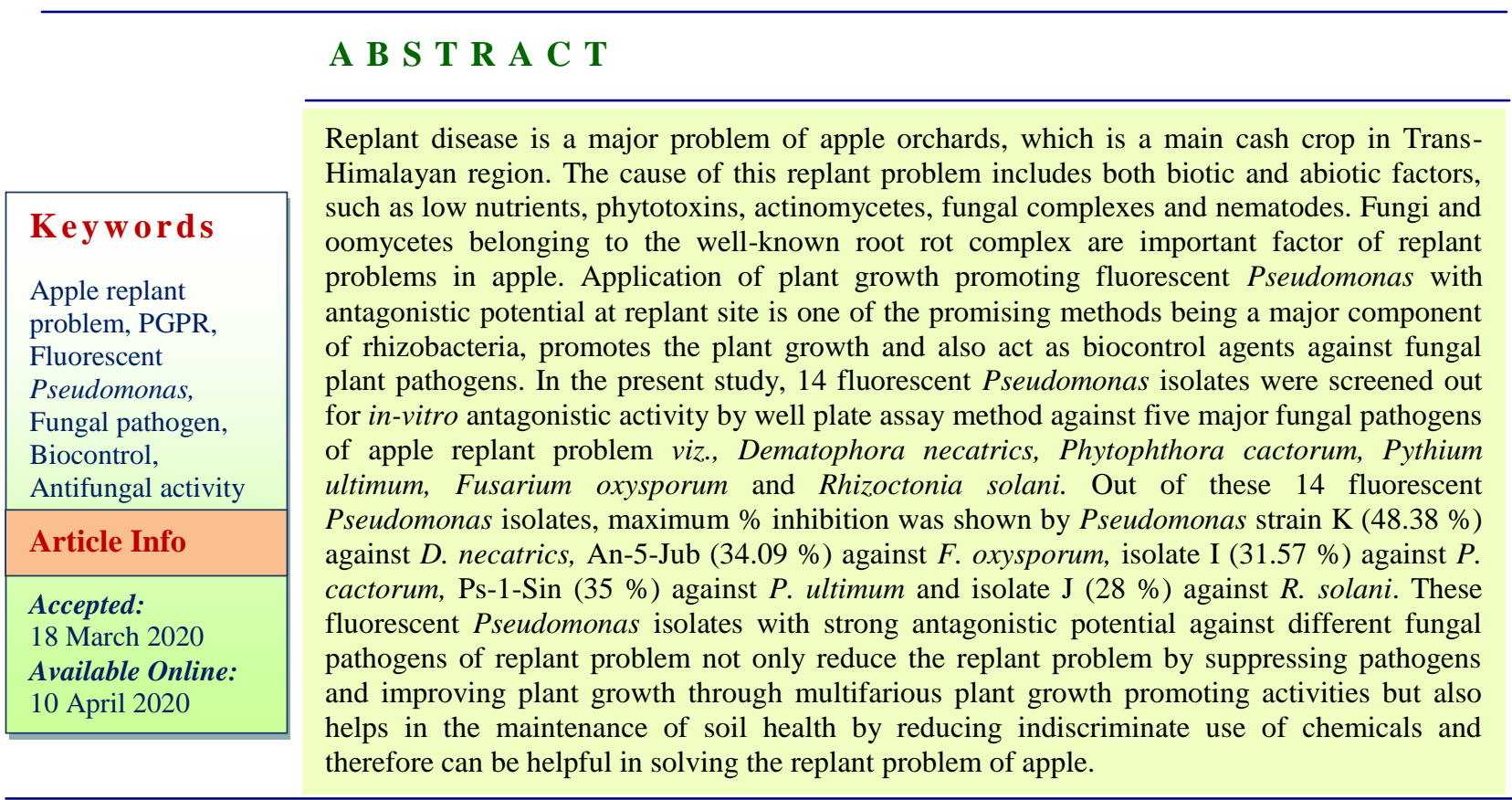

\section{Introduction}

Apple replant disease (ARD) is a disorder caused by a complex of fungal, bacterial and nematode pathogens that affect tree fruit crops when planted on sites where those crops were previously grown and directly affect the yield as compared to healthy trees
(Winkelmann et al., 2019). In past years, ARD was managed with preplant soil fumigation with methyl bromide or treatment with organophosphate biocides (Mai and Abawi, 1981) but those materials have been or are being phased out due to environmental concerns. Presently recommended practices to mitigate ARD in new orchards include 
preplant cover copping, multi-year fallow periods and use of resistant rootstocks (Merwin et al., 2001), but those practices are not always effective in supporting optimum tree growth (Robinson, 2007).

To overcome this problem, application of plant growth promoting bacteria at replant site has been proved to be one of the promising approaches. Plant growth-promoting rhizobacteria (PGPR) occur naturally in soil and in the vicinity of roots of the plant where they colonize the roots and provide benefits to the plant by multifarious plant growth promoting activities (Braun and Fuller, 2006). Plant growth promoting rhizobacteria facilitate the plant growth through $\mathrm{N}_{2}$ fixation, solubilization of insoluble phosphate (P), production of siderophores, phytohormones production, lowering of ethylene concentration, production of antibiotics and antifungal metabolites (Lugtenberg and Kamilova, 2009; Tank and Saraf, 2010; Zaidi et al., 2009). Different PGPR's and endophytes have been reported useful to enhance the yield of different agricultural produce including different cereals, vegetables \& spices etc. Presently, PGPR and endophytes are being used progressively individually as well as consortia of two or more strains also in combination with manures and fertilizers for improving crop yields and reducing the use of chemical fertilizers thus, contributing towards the advancement of sustainable agricultural systems.

Fluorescent Pseudomonas sp. are the most diverse and versatile group of indigenous micro flora of almost all the horticulture and forestry crops. Their potential to synthesize different secondary metabolites with diverse biological activities is the important function of soil fertility and sustainability of crops. These organisms may be ideal for use as plant growth promoting and disease suppressing bioagents. The integration of their important traits like production of antifungal antibiotics, iron chelating siderophores, lytic enzymes, plant growth regulators, phosphate solubilization, ammonia and HCN production with ecological fitness of the strains will be prerequisite for designing useful, efficient and effective novel bio agent (Malik, 1982; Kaur et al., 2011; Kapoor et al., 2012).

Pseudomonads possess many traits that make them well suited as biocontrol and plant growth-promoting agents. The Pseudomonas sp. are well known for their involvement in the biocontrol of several plant pathogens (Antoun and Prevost, 2005). The selection of effective strains of particular bacteria is of prime importance for the biocontrol of plant pathogens. Isolation of bacteria from pathogen suppressive soils may increase the chances of finding effective strains (Cook and Baker, 1983). The biocontrol mechanism Pseudomonas spp. normally involves the production of antibiotics, hydrolytic enzymes and secondary metabolites which suppress the fungal pathogens. P. fluorescens has a gene cluster that produces a suite of antibiotics, including compounds such as 2,4diacetylphloroglucinol (DAPG), phenazine, pyrrolnitrin, pyoluteorin and biosurfactant antibiotics which have been reported among antifungal mechanisms by which Pseudomonas strains inhibited the fungal growth through damaging of cell walls (Angayarkanni et al., 2005; Sindhu and Dadarwal, 2001). Pseudomonas aeruginosa produced several metabolites which were active against many pathogenic fungi and bacteria such as phenazine compound and its derivatives. There were more than 80 heterotrocyclic nitrogen-containing natural products of phenazines synthesized by fluorescent Pseudomonas spp. (Blankenfeldt et al., 2004). Fluorescent Pseudomonas is uniquely capable of synthesizing many of these antibiotics, not only to enhance its own 
fitness but also to help in the maintenance of soil health and bioprotection of crops from pathogens (Dubey and Patel, 2001).Therefore to exploit the potential of fluorescent Pseudomonas isolates, the present study was aimed at in- vitro evaluation of antifungal activity of potential fluorescent Pseudomonas isolates against major plant pathogens involved in apple replant problem.

\section{Materials and Methods}

Plant growth promoting fluorescent Pseudomonas isolates isolated from apple replant sites were evaluated for antagonistic activity against major fungal pathogens involved in apple replant problem. 14 isolates of Pseudomonas sp. were tested for antifungal activity by standard well/bit plate assay method (Vincent, 1947). Fungal pathogens used in this study were isolated from apple replant sites. Fresh culture bits (10 mm dia) of 5 days old indicator fungi were cut with the help of sterile well borer and placed on the one side of prepoured malt extract agar (MEA) plates with the help of sterile inoculating needle. On the other side of plates, $10 \mathrm{~mm}$ well was cut with the help of sterile cork borer. $100 \mu \mathrm{l}$ of $72 \mathrm{~h}$ old cell free culture supernatant of each test bacterial isolates was added to each well $(10 \mathrm{~mm})$. Plates were incubated at $28 \pm 2^{\circ} \mathrm{C}$ for 5-7 days and for Phytophthora cactorum, plates were incubated $28 \pm 2{ }^{\circ} \mathrm{C}$ for $48 \mathrm{~h}$ and observed for inhibition zone produced around the well. For control culture bit of indicator fungi kept in the centre of MEA plate and incubated at $28 \pm 2{ }^{0} \mathrm{C}$ for 4 days. Antifungal activity expressed in terms of $\mathrm{mm}$ diameter of mycelial growth and that in turn expressed as per cent inhibition of fungal mycelia growth as calculating from equation:

Percent Inhibition $(\% \mathrm{I})=\frac{\mathrm{C}-\mathrm{T}}{\mathrm{C}} \times 100$ where,

$\mathrm{C}$ : growth of mycelium in control

$\mathrm{T}$ : growth of mycelium in treatment

\section{Results and Discussion}

The present study showed that all bacterial isolates showed inhibition of fungal pathogens related to apple replant disease (Table 1 and Figure 1). Antifungal activity against plant pathogen Dematophora necatrics has been showed by nine isolates of Pseudomonas sp. in the range of 12.90 to $48.38 \%$ inhibition. Maximum inhibition was shown by Pseudomonas strain K (48.38\%) followed by $\mathrm{J}(41.93 \%)$.

Ten isolates showed antifungal activity against Fusarium oxysporum in the range of 9.09 to $34.09 \%$ whereas no inhibition was observed in case of other four isolates against this test fungus. Maximum inhibition was shown by An-5-Jub (34.09 \%) followed by four isolates i.e. J, Ar-2-Sh, An-4-Jub and Ps1-Sin showed less inhibition of this plant pathogen i.e. $(27.27 \%)$. Eight isolates of Pseudomonas sp. out of fourteen showed inhibition against Phytophthora cactorum in the range of 7.89 to $31.57 \%$. Maximum inhibition was shown by isolate I $(31.57 \%)$ followed by Ar-4-De (26.31\%). Antifungal activity against plant pathogen Pythium ultimum has been shown by eight isolates of Pseudomonas sp. in the range of 22.5 to 35 $\%$. Maximum inhibition was shown by Ps-1Sin $(35 \%)$ followed by two isolates i.e. B $(32.5 \%)$ and I (30\%). Nine isolates showed antifungal activity against Rhizoctonia solani in the range of 8 to $28 \%$ whereas no inhibition was observed in case of other five isolates against this test fungal pathogen. Maximum inhibition was shown by J (28\%) followed by two isolates i.e. $\mathrm{K}$ and $\mathrm{M}$ showed less inhibition against this plant pathogen i.e. $(20 \%)$. 
Table.1 Potential of fluorescent Pseudomonas isolates for production of plant growth promoting activities: Antifungal against fungal pathogens:- viz, Dematophora necatrix, Fusarium oxysporum, Phytophthora cactorum, Pythium ultimum and Rhizoctonia solani

\begin{tabular}{|c|c|c|c|c|c|c|c|c|c|c|}
\hline \multirow{3}{*}{$\begin{array}{l}\text { Fluorescent } \\
\text { Pseudomonas } \\
\text { Isolates }\end{array}$} & \multicolumn{10}{|c|}{ Percent inhibition of fungal pathogens* } \\
\hline & \multicolumn{2}{|c|}{$\begin{array}{l}\text { Dematophora necatrix } \\
(\mathrm{C}=62 \mathrm{~mm})\end{array}$} & \multicolumn{2}{|c|}{$\begin{array}{l}\text { Fusarium oxysporum } \\
(\mathrm{C}=44 \mathrm{~mm})\end{array}$} & \multicolumn{2}{|c|}{$\begin{array}{l}\text { Phytophthora cactorum } \\
\text { (C=38mm) }\end{array}$} & \multicolumn{2}{|c|}{$\begin{array}{l}\text { Pythium ultimum } \\
(\mathrm{C}=40 \mathrm{~mm})\end{array}$} & \multicolumn{2}{|c|}{$\begin{array}{l}\text { Rhizoctonia solani } \\
\quad(\mathrm{C}=50 \mathrm{~mm})\end{array}$} \\
\hline & $\begin{array}{c}\text { mm } \\
\text { dia }\end{array}$ & $\%$ Inhibition & $\begin{array}{c}\text { mm } \\
\text { dia }\end{array}$ & $\%$ Inhibition & $\begin{array}{c}\text { mm } \\
\text { dia }\end{array}$ & $\%$ Inhibition & mm dia & \% Inhibition & $\underset{\text { dia }}{\mathrm{mm}}$ & $\begin{array}{c}\% \\
\text { Inhibition }\end{array}$ \\
\hline P. aeruginosa I & 38 & $38.70(38.54)$ & 37 & $15.90(23.35)$ & 26 & $31.57(34.16)$ & 28 & $30(33.19)$ & 44 & $12(3.59)$ \\
\hline P. aeruginosa $\mathbf{J}$ & 36 & $41.93(40.22)$ & 32 & $27.27(31.46)$ & - & $0(0.00)$ & 31 & $22.5(28.30)$ & 36 & $28(5.38)$ \\
\hline P. aeruginosa $\mathrm{K}$ & 32 & $48.38(44.05)$ & 40 & $9.09(17.52)$ & 30 & $21.05(27.28)$ & 29 & $27.5(31.61)$ & 40 & $20(4.58)$ \\
\hline P. aeruginosa $\mathrm{B}$ & 42 & $32.25(35.00)$ & 33 & $25(29.98)$ & - & $0(0.00)$ & 27 & $32.5(34.74)$ & 42 & $16(4.12)$ \\
\hline P. putida $\mathrm{L}$ & - & $0(0.00)$ & 33 & $25(29.98)$ & - & $0(0.00)$ & 31 & $22.5(28.30)$ & - & $0(1.00)$ \\
\hline P. fluorescens $\mathbf{M}$ & - & $0(0.00)$ & - & $0(0.00)$ & - & $0(0.00)$ & 30 & $25(29.98)$ & 40 & $20(4.92)$ \\
\hline P.poae Ar-2-Sh & - & $0(0.00)$ & 32 & $27.27(31.46)$ & - & $0(0.00)$ & - & $0(0.00)$ & 46 & $8(2.48)$ \\
\hline $\begin{array}{l}\text { Pseudomonas sp. An-4- } \\
\text { Jub }\end{array}$ & 54 & $12.90(21.02)$ & 32 & $27.27(31.46)$ & 34 & $10.52(18.90)$ & - & $0(0.00)$ & - & $0(1.00)$ \\
\hline $\begin{array}{l}\text { Pseudomonas sp. An-5- } \\
\text { Jub }\end{array}$ & 52 & $16.12(24.14)$ & 29 & $34.09(35.70)$ & 31 & $18.42(25.39)$ & 29 & $27.5(31.61)$ & 45 & $10(3.30)$ \\
\hline Pseudomonas sp. Ar-2-De & 48 & $22.58(28.35)$ & - & $0(0.00)$ & 29 & $23.68(29.10)$ & - & $0(0.00)$ & - & $0(1.00)$ \\
\hline Pseudomonas sp. Ar-4-De & 43 & $30.64(33.59)$ & - & $0(0.00)$ & 28 & $26.31(30.84)$ & - & $0(0.00)$ & 43 & $14(3.87)$ \\
\hline $\begin{array}{l}\text { Pseudomonas sp. Ar-14- } \\
\text { De }\end{array}$ & - & $0(0.00)$ & - & $0(0.00)$ & - & $0(0.00)$ & - & $0(0.00)$ & 41 & $18(4.35)$ \\
\hline $\begin{array}{l}\text { Pseudomonas sp. Ps-1- } \\
\text { Mgn }\end{array}$ & 48 & $22.58(28.35)$ & 33 & $25(29.98)$ & 35 & $7.89(16.28)$ & - & $0(0.00)$ & - & $0(1.00)$ \\
\hline Pseudomonas sp. Ps-1-Sin & - & $0(0.00)$ & 32 & $27.27(31.46)$ & 32 & $15.7(23.33)$ & 26 & $35(36.25)$ & - & $0(1.00)$ \\
\hline C.D $D_{0.05}$ & & 1.322 & & 1.054 & & 1.081 & & 1.101 & & 0.344 \\
\hline
\end{tabular}



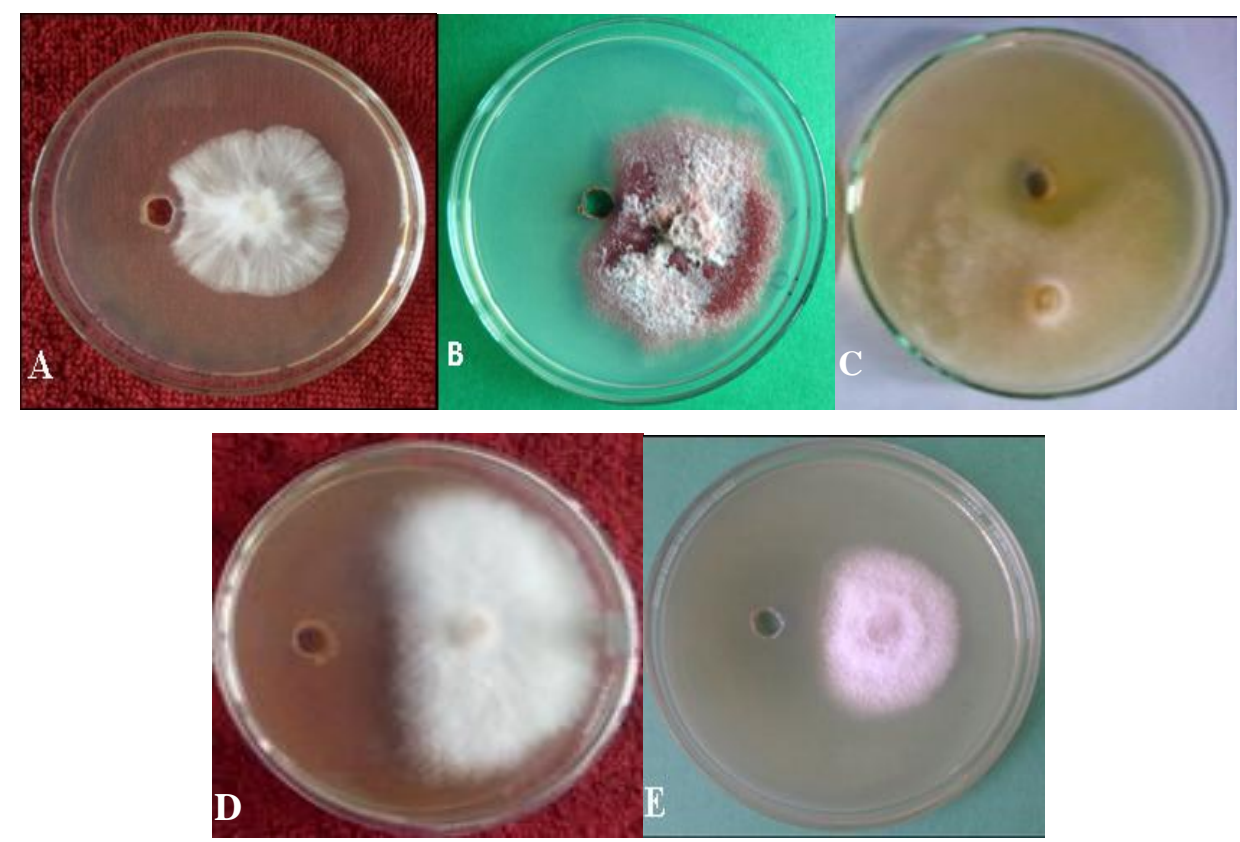

Figure.1 Antifungal activity shown by Pseudomonas isolates against different fungal pathogens at $28 \pm 2{ }^{\circ} \mathrm{C}$ :- viz.,(A) Dematophora necatrix, (B) Fusarium oxysporum, (C) Phytophthora cactorum, (D) Pythium ultimum and (E) Rhizoctonia solani

Reddy et al., (2007) also reported that crude compounds from $P$. fluorescens isolates metabolites completely inhibited the growth of Magnaporthe grisea, Dreschelaria oryzae, Rhizoctonia solani and Sacrocladium oryzae at $5 \%$. The antifungal activity of fluorescent Pseudomonas sp. against phytopathogens viz., Fusarium sp., Pythium sp., Phytophthora sp., Dematophora sp. and Alternaria sp. has a strong potential for plant growth promotion by inhibiting fungal pathogens and is also helpful in solving the replant problem of apple in field conditions (Sharma et al., 2013).

Pseudomonas chlororaphis, Pseudomonas fluorescens and Pseudomonas putida isolated from the rhizospheres of healthy avocado trees showed antagonistic activity against Dematophora necatrix, the cause of avocado Dematophora root rot (also called white root rot) (Cazorla et al., 2006). Berta et al., (2004) studied the ability of Glomus mosseae BEG12 and Pseudomonas fluorescens A6RI to suppress rhizoctonia root rot (Rhizoctonia solani) of tomato and observed that both beneficial strains suppressed the soil borne disease.

This suppression was related to microbial antagonism and induced resistance for both strains. Sharma and Bhardwaj (2005) evaluated Bacillus spp. NA1, Bacillus subtillus-2, E. aerogenes-3 and P. fluorescens KB6 in controlling two important soil borne diseases of apple, viz. collar rot (Phytophthora cactorum) and root rot (Dematophora necatrix) and observed significant reduction in growth of these fungal pathogens further these isolates were effective against root rot pathogen under pot culture conditions and provided disease control of 72.3-82.1\%.

All the plant growth promoting fluorescent Pseudomonas isolates showed antifungal activity against five test indicator plant pathogenic fungi isolated from replant sites of apple in the range of 7.8- 48.3 per cent. These plant growths promoting rhizobacteria can 
consequently act as an effective biological control agent against fungal plant pathogens since the rhizosphere provide the front line defense for roots against attack by pathogen. Thus these fluorescent Pseudomonas isolates can be helpful in solving the replant problem of apple in field conditions.

\section{References}

Angayarkanni T, Kamalakannan A, Santhini E and Predeepa D. 2005. Identification of biochemical markers for the selection of Pseudomonas fluorescens against Pythium spp. In: Asian conference on emerging trends in plant-microbial interactions. University of Madras, Chennai. pp. 295-303

Antoun H and Prevost D. 2005. Ecology of plant growth promoting rhizobacteria In: PGPR: biocontrol and biofertilization. Siddiqui Z A (ed.). Springer, Dordrecht: The Netherlands. pp. 1-38

Berta G, Sampo S, Gamalero E, Massa N and Lemanceau P. 2004. Suppression of Rhizoctonia root rot of tomato by Glomus mosseae BEG12 and Pseudomonas fluorescens A6RI is associated with combined modes of action. Bulletin-OILB/SROP 27(8): 99

Blankenfeldt W, Kuzin PA, SkarinaT, Korniyenko Y, Tong L, Bayer P, Thomashow SL and Mavordi DV. 2004. Structure and function of phenazine biosynthetic protein $\mathrm{PhzF}$ from Pseudomonas fluorescence. Biochemistry 101: 16431-16436

Braun PG and Fuller KK. 2006. Biological control of apple replant disease. Canadian Journal of Plant Pathology 28: 326

Cazorla F M, Duckett S B, Bergstrom E T, Noreen S, Odijk R, Lugtenberg B J J, Thomas-Oates J E and Bloemberg G V. 2006. Biocontrol of avocado
Dematophora root rot by antagonistic Pseudomonas fluorescens PCL1606 correlates with the production of 2hexyl 5-propyl resorcinol. Molecular Plant Microbe Interaction 19(4): 418428

Cook RJ and KF Baker. 1983. The nature and practice of biological control of plant pathogens. The American Phytopathological Society. pp. 539

Dubey SC and Patel B. 2001. Determination of tolerance in Thanatephorus cucumeris, Trichoderma viride, Gliocladium virens and Rhizobium sp. to fungicides. Indian Phytopathology 54: 98-101

Kapoor R, Kumar A, Patil S, Thapa S and Kaur M. 2012. Evaluation of plant growth promoting attributes and lytic enzyme production by fluorescent Pseudomonas diversity associated with apple and pear. International Journals of Scientific and Research Publication 2(2): 1-8

Kaur M, Kumar S, Sharma S, Rana V and Sharma G. 2011. Potential of indigenous strains of Pseudomonas and Bacillus species for production of plant growth regulators viz., auxin, gibberellins and cytokinins from carnation and medicinal plants. Progressive Horticulture 43(1): 1-10

Lugtenberg B and Kamilova F. 2009. Plant growth promoting rhizobacteria. Annual Review of Microbiology 63: 541-556

Mai WF and Abwai GS. 1981. Controlling replant diseases of pome and stone fruits in Northeastern United States by a preplant fumigation. Plant Diseases 34: 254-267

Malik VS. 1982. Genetic and biochemistry of secondary metabolites. Applied Microbiology 28: 28-101

Merwin IA, Byard R, Robinson TL, Carpenter $\mathrm{S}$, Hoying SA, Iungerman KA and Fargione M. 2001. Developing an 
integrated program for diagnosis and control of apple replant disease. Horticultural Science 23: 791

Reddy L, Moradi F and Koch C. 2007. Topdown biases win against focal attention in the fusiform face area. NeuroImage 38: 730-739

Robinson TL. 2007. Common mistakes in planting and establishing high-density apple orchards. New York Fruit Quart 15(4): $1-7$

Sharma IM and Bhardwaj SS. 2005. Bacterial antagonists in management of collar rot and root rot diseases in apple. Acta Horticulturae 696: 349-354

Sharma S, Kumar M and Kaur M. 2013. Comparative study of the siderophores produced by Pseudomonas sp. isolated from apple rhizosphere of TransHimalayan region: potential utilization in replant problem and development of biosensor. Asian Journal of Science and Technology 4(12): 27-36

Sindhu SS and Dadarwal KR. 2001. Chitinolytic and cellulolytic Pseudomonas spp. antagonistic to fungal pathogens enhances nodulation by Mesorhizobium spp. cicer in chickpea. Microbiology Reviews 56: 662-676

Tank N and Saraf M. 2010. Salinity-resistant plant growth promoting rhizobacteria ameliorates sodium chloride stress on tomato plants. Journal of Plant Interactions 5: 51-58

Vincent JM. 1947. Distribution of fungal hyphae in presence of certain inhibitors. Nature 150: 158-850

Winkelmann T, Smalla K, Amelung W, Baab G, Stöcker G, Kanfra X, Meyhöfer R, Reim S, Schmitz M, Vetterlein D, Wrede A, Zühlke S, Grunewaldt J, Wei S and Schloter M. 2019. Apple replant disease: causes and mitigation strategies. Current Issues in Molecular Biology 30: 89-106

Zaidi A, Khan MS, Ahemad M and Oves M. 2009. Plant growth promotion by phosphate solubilizing bacteria. Acta Microbiological Et Immunological Hungarica 56: 263-284.

\section{How to cite this article:}

Neha Kaushal and Mohinder Kaur. 2020. Antagonistic Activity of Plant Growth Promoting Fluorescent Pseudomonas spp. against Major Fungal Pathogens Involved in Replant Problem of Apple. Int.J.Curr.Microbiol.App.Sci. 9(04): 2285-2291.

doi: https://doi.org/10.20546/ijcmas.2020.904.273 